\title{
An Examination and Analysis of Division I Football Game Contracts: Legal Implications of Game Cancellations Due to Hurricanes
}

\author{
Jessica R. Murfree and Anita M. Moorman
}

In recent years, extreme weather events, namely hurricanes, have compromised the college football schedule in the United States. Incidents of extreme weather have caused the cancellation, postponement, relocation, or otherwise alteration of dozens of Division I college football games in recent years. Focusing primarily on hurricanes, this study will present several concerns related to these storms and extreme weather in the US, and contractual law principles of common law defenses and force majeure clauses as they relate to college football game contracts. The purpose of the present study is to begin to better understand the football game contract inconsistencies that can lead to legal disputes faced by college football programs that deal with these storms, and gain a better insight of the contractual considerations made in light of these storms that are becoming increasingly frequent and severe. To do so, college football game contracts were obtained through Freedom of Information Act (FOIA) requests to select NCAA Division I colleges, internet-based searches, and media exchanges.

Analysis of force majeure contract language revealed inconsistent definitions of force majeure events, a limited number of contracts containing specific weatherrelated force majeure language, and a range of force majeure events leading to the absence of a clear and consistent understanding of how extreme weather-related cancellations would impact the contractual relationships. Recommendations, as a result of the document analysis, are then made for provisionary revision and reconstruction to meet current realistic needs for individual schools. Societal consciousness regarding climate change is adjusting, therefore sport and legal practitioners can reflect this modernization by scrutinizing potential prudent risks.

Keywords: college football, game contracts, NCAA, extreme weather, hurricanes, climate change, common law, force majeure

Jessica Murfree, MA, is a PhD candidate and instructor in the sport administration program at the University of Louisville. She researches the intersections of climate change, extreme weather, and sport, with a focus on social and legal outcomes. Email: jessica.murfree@louisville.edu

Anita Moorman, JD, is a professor of sport administration in the Department of Health \& Sport Sciences at the University of Louisville. Her research interests includes contractual relations in sport, participant rights in sport and the interplay between sport law and marketing. Email: anita. moorman@louisville.edu 


\section{Introduction}

Devastating natural disasters occur annually in the United States, and society has become accustomed to high-category hurricanes with winds that demolish coastal communities, often producing severe floods that destroy infrastructures and the lives of many (Dinan, 2017; Goldfarb, 2005). Society's acclimatization to natural disasters is due simply to the fact that these events, "are not new and unfamiliar occurrences across the United States" (Sniffen, 2007, p. 552). Also, not unfamiliar in the US, is the onset of college football season each fall. Because events of extreme weather, particularly hurricanes, continuously occur, significant consideration should be made with regards to college football game contractual obligations that govern every game. Should either party fail to perform due to a hurricane and seek relief for doing so, it is important to consider the legal protections that may exist to excuse performance.

Common to college football game contracts are clauses known as force majeure or impossibility clauses, which attempt to provide for disruptive events that make it impossible or impracticable for a party to perform. These clauses are designed to excuse one or both parties from its contractual obligations in the event non-performance is due to one of these disruptive events, thus avoiding a breach of contract. However, force majeure provisions are often boilerplate in nature, may not be reviewed or updated regularly, and may fail to consider the relevant advances of climate change and forces of nature that have significantly impeded college football games in recent years. Additionally, individual institutions and conferences can draft contracts independently from one another, providing for a lack of consistency in contract drafting. Accordingly, varying language used, and differing interpretations have led to disputes and litigation.

Therefore, the purpose of this study is to (a) provide an overview of the effects and prevalence of recent hurricanes on the college football season in the US, (b) examine the legal contexts and relationships between force majeure clauses and common law defenses of impossibility and impracticability in the context of game cancellations, (c) analyze existing language in college football game contracts, and (d) discuss recommendations for contract drafting and negotiations that will accommodate an ever-changing natural environment.

\section{Impacts of Hurricanes on College Football in the United States}

Hurricane season in the US and the college football regular season almost perfectly overlap and appear to have a stronger relationship in recent years. This parallelism, in fact, has ignited discussion on extending the college football season 
purposefully to avoid hurricanes (Russo, 2018). Perfect hurricane conditions require steady winds and a surface water temperature of at least 79 degrees Fahrenheit (May, 2017). The National Oceanic and Atmospheric Administration's (NOAA) Geophysical Fluid Dynamics Laboratory (GFDL), as well as the United States Environmental Protection Agency (EPA), have been able to find increasing correlations between Atlantic Oceanic hurricane activity and tropical Atlantic sea surface temperatures, signifying the relationship between climate change and the presence of hurricanes. Current statistical models indicate moderate to high increases in Atlantic hurricane activity, as measured by the Power Dissipation Index (PDI), due in part to anthropogenic greenhouse gas emissions, thus partly attributing hurricanes to human behavior (Geophysical Fluid Dynamics Laboratory, 2018). As such, states along the Atlantic and gulf coasts seemingly have been bracing for hurricane impact every year in anticipation.

While the cancellation of football games due to extreme weather is not a new phenomenon (e.g., UCLA at Miami cancelled by 1998's Hurricane George, Crowe, 1998), these natural disasters have now become the new normal. September 2017's Hurricane Irma was reported to be the "longest-lasting powerful hurricane," spending several days as a Category 5 storm, and college football games suffered in her wrath (Chappell, 2017, para. 1; Cangialosi, Latto, \& Berg, 2018). In 2017 alone, nearly two dozen NCAA Division I college football teams' coaches, staff, and athletic administrators were forced to abruptly juggle travel implications, refunds, and accommodations required for event management as Irma's potential landfall destruction loomed in daily forecasts (Berkowitz, 2017; Culpepper, 2017; Kirk \& Godfrey, 2017; Spain, 2017). Furthermore, the impact of the 2017 hurricane season on football stretched beyond the collegiate level, and beyond coastal regions, forcing over 50 high schools in Kentucky to reschedule games in preparation for Hurricane Harvey (Moore, 2017). Additionally, 16 total games were impacted by 2018's Hurricane Florence, which notably adjusted games for five top-20 ranked teams, three of which were cancelled entirely (USA Today Sports, 2018). Further, three games were adjusted due to 2019's Hurricane Dorian, and meteorologists predicted the 2020 hurricane season would further exacerbate college football hardships caused by the novel coronavirus pandemic (Miller \& Rice, 2020; Murray, 2020; Varriale-Barker, 2020; West, 2020).

While football is often the gateway into a university, it also serves as the financial lifeline for institutions (Katz, Dixon, Heere, \& Bass, 2017; Wong, n.d.). With so few games in a season compared to other sports, and premium broadcasting deals, it becomes difficult for universities to afford game cancellations. However, anticipation of natural disasters in the US can be alleviated with event cancellation insurance, which can provide financial protection against 
catastrophes like hurricanes (Wong, n.d.). While investing in such policies can appear to be another monetary burden, impacted games force opponents and other scheduled teams to cooperate in rescheduling, making the insurance price tag more appealing than managing extensive losses (Culpepper, 2017; Spain, 2017; Wong, n.d.). As a result, athletic departments experienced an estimated \$10-15 million in weather-related losses in 2017 and estimated economic losses due to Hurricane Florence to be competitive with the previous year (Wong, n.d.). In addition to damage-related costs as a result of extreme weather, college football game contracts often dictate significant costs should the game go unperformed.

\section{Legal Theories Related to Excuses for Non-Performance of Game Contracts}

Typically, when a party to a contract fails to live up to the obligations imposed under the contract, this non-performance would be considered a breach of contract entitling the non-breaching party to recover damages. However, within contract law, defenses exist to excuse performance should either party have an acceptable reason for breaching the contract. In some circumstances, a party may have its performance of the contractual obligations excused or eliminated based on a number of legal theories such as illegality, unconscionability, fraud, duress, public policy, mistake, impossibility, impracticability, and frustration of purpose (Lau \& Johnson, 2011).

In the context of a game cancellation due to an extreme weather event, the most likely theories available to the canceling party for non-performance would either be based on common law theories of impossibility and impracticability, or derived from a force majeure clause included in the underlying game contract. The parties to a contract are encouraged, and well-advised, to anticipate events that could lead to non-performance and stipulate in the contract how the parties will allocate that risk, what circumstances would rise to the level of a force majeure event, and what effect such an event would have on the rights and obligations of the parties to the agreement (Encinas, 2020; Katsivela, 2007; Sniffen, 2007). The present study serves as an examination of the law as it relates to the interpretation and enforcement of force majeure provisions in contracts generally, and an exploration of how those general principles might impact the types of force majeure provisions analyzed in 36 NCAA Division I football game contracts. The following section explores whether the common law defenses of impossibility or impracticability may supplement the available force majeure defenses for game cancellations. 


\section{Common Law: Impossibility and Impracticability}

On a basic level, contracts can be understood as risk allocation devices wherein a perfect contract allocates all risks clearly and efficiently (Brener, 2006). However, early Roman civil law, British Common Law, and eventually modern U.S. common law have all recognized some form of defense to performing a contract due to unforeseen circumstances or consequences rendering such performance impossible (Brener, 2006). Today, the common law doctrines of impossibility and commercial impracticability are particularly relevant to understanding performance obligations arising under game contracts impacted by extreme weather. Kelley (2007) observed these two doctrines often establish the default rules around which a party to a contract may be excused from their performance obligations. Since these default rules associated with common law impossibility and impracticability are often also applied in cases in which contractual force majeure rights exist, exploring the breadth and limitations of these doctrines will supplement our understanding of force majeure in the next section.

The defense of impossibility asserts that an external event could make the contract's performance impossible (Hall, 2017). Courts agree for an event to qualify as rendering a contract impossible, it must be both unforeseen and must destroy an essential matter of the contract's performance (Hall, 2017; Meyers \& Sheinkin, 2012). Impossibility of performance typically requires a circumstance beyond either party's control, or "situations where parties cannot take actions to protect themselves from risk" (Sniffen, 2007, p. 11). Because of these restrictive factors, the defense of impossibility is not applied broadly.

For example, in the State of Florida (where a number of event cancellations are due to hurricanes or other extreme weather events) under the common law doctrine of impossibility, a party is discharged from performing a contractual obligation in which it is impossible to perform and the party did not assume the risk of impossibility, and could not have acted to prevent the event from rendering performance impossible (see Marathon Sunsets, Inc. v. Coldiron, 2016). Thus, under this doctrine, in order to prove this defense, the plaintiff must show:

1. An event occurred making performance impossible or impracticable;

2. The party seeking relief must not have been at fault in causing the event to occur;

3. The non-occurrence of the event must have been a basic assumption upon which the contract was made; and

4. The party seeking relief must not have assumed the risk of the event occurring. (Restatement of Contracts § 261) 
The fourth element under the Restatement test limits the application of the impossibility defense if the relevant business risk was foreseeable at the inception of the agreement and was, or could have been, subject of an express provision of the agreement (Am. Aviation, Inc. v. Aero-Flight Serv., Inc, 1998).

Because impossibility generally requires objective impossibility (i.e., performance cannot be done), occasions of mere increased difficulty associated with performance do not fall under its scope. In these instances, increased costs that could have been anticipated by the parties, or strategic business decisions impacting one party's ability to perform due to financial limitations, will not normally qualify as impossibility. In Urban Archaeology v. 207 East 57th Street, 34 Misc.3d 1222(A) 951 N.Y.S.2d 84 (N.Y. Co. 2009), a commercial tenant in New York claimed 2009's economic crisis made its performance, as dictated by the lease, impossible. Ultimately, the claim was dismissed despite the economic crisis' severity. The court's rejection considered that a prominent party could anticipate having financial difficulties, denying impossibility of performance (Hall, 2017).

Unlike impossibility, which typically requires that performance is objectively impossible, the defenses of frustration of purpose and impracticability may apply. The frustration of purpose doctrine is predicated on the premise of giving the parties relief where they could not have provided for themselves by the terms of the contract. This defense would not be available where the intervening event was reasonably foreseeable and could and should have been controlled by provisions in the contract (Hilton Oil Transport v. Oil Transport Co., 1995). In contrast, the defense of impracticability excuses performance due to unanticipated facts or circumstances that would cause extreme and unreasonable difficulty to perform the contractual obligations. Because increased costs or logistical challenges alone do not excuse performance, the costs or challenges must be both extreme and unreasonable (Dellinger, 2016). Additionally, the burden of proof will be upon the party seeking to avoid performance to demonstrate the extreme and unreasonable effect of the circumstances.

The subtle differences between common law defenses illustrate challenges faced by universities when considering the potential disputes that may arise among institutions seeking relief upon cancellation of a football game due to a hurricane or extreme weather event that does not destroy a venue or wholly prevent travel, but creates uncertainty surrounding travel schedules, increased costs, or logistical challenges. In such circumstances, whether performance is rendered impossible or impracticable becomes a question that is not clearly resolved by either of these common law defenses. The scope and limitations of the common law doctrines of impossibility and impracticability highlight the 
importance and significance of drafting force majeure clauses in such a way that the parties are efficiently anticipating and allocating potential risks.

\section{Force Majeure}

Of French origin meaning "a supervening or superior force," force majeure clauses exist in contracts to define such events that are unanticipated or uncontrollable, or impactful circumstances like war, labor stoppages, fire, riots, and other extremes that would excuse the parties of their contractual obligations (Sniffen, 2007). Force majeure provisions are intended to acknowledge that an event can occur, making performance by either party impossible. If this event were to happen, the provision provides that neither party is held liable for breach of contract, thus neither party will sue the other. It is, in essence, a no-fault termination of the agreement. The force majeure clause should be the only clause in the contract addressing the issue of changed circumstances and performance of the contract (Declercq, 1995).

Although often used interchangeably, force majeure is considered by courts to be a more expansive term than an "act of God," and can be applied to a circumstance occurring outside of the parties' control brought on both by natural and human means (Dellinger, 2016; 1 Am Jur 2d Act of God § 2, 2005). An act of God is defined as "a natural catastrophe which no one can prevent such as an earthquake, a tidal wave, a volcanic eruption, a hurricane or a tornado" ("Act of God," n.d.). Thus, extreme weather events would normally fall under a broad understanding of acts of God, but are often also specifically identified within the scope of a force majeure event in a contract. According to Encinas (2020), force majeure typically covers three main categories of events: (1) acts of God or natural forces, (2) human events, and (3) performance failures.

Common to modern college football game contracts, force majeure provisions claim that neither team will be held liable for failed contractual obligations should one of the specifically listed events occur, and will often mention a wide range of events including natural forces such as fire or floods, human events such as war or riots, and performance failures such labor disputes and NCAA probation. The impact of natural forces and the usage of and reliance upon force majeure provisions in contracts has gained significance since catastrophic natural disasters like 2005's Hurricane Katrina (Bergin, 2005). In an effort of reinforcement in avoiding unnecessary risks, a force majeure clause essentially doubles down on common law principles. Should a force majeure provision clearly state that the triggering event renders contractual obligations impossible, its legal enforcement becomes considerably narrow (Sniffen, 2007).

While the presence of force majeure clauses in college football game contracts is commonplace, the determination of whether they are serving their 
purpose is not. In protecting the parties' interests, game contracts should also very clearly state the requirements to excuse performance should it become impossible or impracticable to play. When assessing hurricanes specifically, the occurrences of these storms are generally foreseeable, but the range of potential interfering impacts are not always easily anticipated. Storm surges, power outages, emergency responses, travel interruptions, mandatory and voluntary evacuations, flooding, and rainfall brought upon by any individual storm's landfall are much less predictable. Foreseeability along a timeline must also be taken into consideration. Whether the specific circumstance presumably causing the inability to perform is unforeseeable at the time of contract formation or at the time of contract execution is questionable (Nestel, 2006). Thus, language used in force majeure clauses in college football game contracts should no longer be routine or boilerplate, but instead should be intentionally crafted to anticipate and allocate risks associated with extreme weather-related cancellations.

\section{Legal Disputes Related to Interpretation of Game Contracts}

College football game contracts tend to be standard agreements that have dictated games' arrangements for decades (Siegfried \& Burba, 2004). While the sophistication of these agreements may vary by division or from one athletic conference to another, most game contracts include liquidated damages to protect the parties from impermissible cancellations given the difficulty of finding replacement opponents on short notice, and managing conference scheduling requirements. A game cancellation creates significant challenges for both parties. Often teams are forced to give up a bye week to reschedule a canceled game. Additionally, the university must be able to find another team that has the same bye week, does not already have 12 regular season games, and has the flexibility in their conference schedule to add the game (Moriarty, 2017). Thus, a game cancellation does indeed cause significant disruption for the parties to the agreement.

For the most part, game contract relationships have been free from significant legal disputes. One of the first notable exceptions was Duke University's decision to cancel its contract with the University of Louisville after their first meeting in 2002. The Cardinals sued to recover liquidated damages, but left empty-handed due to the court's interpretation of the phrase "team of similar stature" included in the game contract to include any football team competing in NCAA Division I. Since Duke's football team was one of the worst teams in the league, any team in the league would constitute a "team of similar stature." Thus, since Louisville had scheduled replacement games for the games Duke refused to appear for, Louisville was not entitled to liquidated damages (University of Louisville $v$. 
Duke University, 2008). In the Duke example, Duke made a business decision to cancel the agreement, and was fortunate to avoid paying damages for their breach. However, recent game cancellations based on weather-related conditions are on the rise, which have resulted in the liquidated damages provisions in these contracts facing off against the force majeure provisions.

Several game cancellations due to weather-related events have resulted in legal disputes regarding the effectiveness of the force majeure clause to excuse the performance of the canceling party (Kubena, 2018; McKewon, 2018a). Arkansas State University sued the University of Miami over its decision to cancel their 2017 game scheduled in Arkansas due to Hurricane Irma's approach in Florida. Additionally, the University of Akron pursued legal action against the University of Nebraska-Lincoln following Nebraska's decision to cancel their 2018 season opener in Lincoln after the game was delayed due to a lengthy thunderstorm. Arkansas State's game contract provided for $\$ 650,000$ in liquidated damages and Nebraska's damage exposure was $\$ 1$ million. Both agreements also contained force majeure provisions that were at the center of the disputes.

For Arkansas State and Miami, the schools entered into a contract agreement using a standard agreement provided by the Atlantic Coast Conference. The contract contained a force majeure clause that stated: "This contract shall be void with respect to any of the games in the event that it becomes impossible to play such game(s) by reason of an unforeseen catastrophe or disaster such as fire, flood, earthquake, war ... or injunctive orders of any competent judicial or other government authority" (Atlantic Coast Conference, 2013, p. 4).

The clause does not identify weather-related force majeure events generally, nor does it provide for hurricanes specifically. Additionally, it does not delineate where the force majeure event needs to occur. Since the game was scheduled in Jonesboro, Arkansas, extreme weather or hurricanes occurring in Florida, even if specified in the force majeure clause, may not render performance impossible. Further, the clause states that "any games not played as scheduled shall be rescheduled as such exigencies may dictate or permit," where there is room for interpretation as to what a reasonable effort to reschedule is (Atlantic Coast Conference, 2013, p. 4). While the Miami team prepared for Hurricane Irma's landfall with the rest of the university, including not traveling, Arkansas State argued that the hurricane would not affect its campus and they would provide hospitable needs should Miami need to extend their trip. Herein lies the source of the schools' dispute, ultimately resulting in legal intervention. The basis of this legal argument rested in the competing interpretation and application of impossibility. Arkansas State contended it was not impossible for a football game to take place in Jonesboro, Arkansas, nor was it impossible for the Miami football program to travel there for the competition. Therefore, Arkansas State sued 
Miami for a breach of contract and requested liquidated damages of $\$ 650,000$ (Atlantic Coast Conference, 2013). In response, Miami asserted a broad reading of the contract's catch-all terminology within the force majeure phrase: "that it becomes impossible to play such game(s) by reason of an unforeseen catastrophe or disaster such as ..." (Atlantic Coast Conference, 2013, p. 4). Miami argued a hurricane would fall within the broad definition of unforeseen catastrophes or disasters, even absent identifying "hurricane" specifically as a force majeure triggering event because of the term "such as." Communication between the universities to address the cancellation and any due damages began via email correspondence as Miami's assistant general counsel detailed the emerging realities the region faced in preparation for the severity, and aftermath, of Hurricane Irma (Rowlee, 2018). Arkansas State asserted Miami's decision to not travel did not qualify under the express terms of the force majeure clause, constituting a material breach of the contract (Phelps, 2018). Ultimately, both parties settled the case with Miami paying $\$ 400,000$ to Arkansas State, thus preventing clarity on how this game contract would have been legally interpreted.

Another game cancellation leading to the threat of litigation involved the $\mathrm{Ne}$ braska v. Akron football game on Sept. 1, 2018. Akron and Nebraska experienced an extensive lightning delay due to a severe thunderstorm striking shortly after kicking off in Lincoln (Sherman, 2018). Nebraska cited public safety concerns, and aimed for rescheduling promptly, but Akron faced logistical difficulties in doing so (Sherman, 2018). For Nebraska, a good faith attempt appeared to have been made in rescheduling, while Akron argues that it was owed either the game guarantee of $\$ 1.17$ million or liquidated damages of $\$ 1$ million, plus expenses, for the mid-game cancellation (Abraham, 2018; Shapiro, 2018). The duration and intensity of the lightning strikes prompted Nebraska to call for the cancellation, acting under the impression that the cancellation was covered within the force majeure provision (Sherman, 2018). However, the force majeure provision of Nebraska and Akron's game agreement states the following:

This agreement shall be void in the event it becomes impossible to play the game by reason of disaster, fire, hurricane, tropical storm, flood, earthquake, war, act of terrorism, invasion, hostilities, rebellion, insurrection, confiscation by order of government, military public authority, or prohibitory or injunctive orders of any competent judicial or other governmental authority. (Shapiro, 2018, para. 3)

Importantly, the force majeure clause in the agreement entered into by Nebraska and Akron specifically listed "tropical storms" and "hurricanes" as contract-voidable force majeure events for these inland states. However, it did not include "severe thunderstorms," "lightning," "inclement weather," or "acts of God" more generally (Shapiro, 2018). Unlike the ACC's template used by 
Miami, the Akron/Nebraska contract's listing of appropriate force majeure events also does not include an encompassing catch-all term like "such as" to potentially incorporate additional acceptable force majeure events that are similar to "tropical storms" and "hurricanes." The potential ambiguity and uncertain interpretation surrounding the Akron/Nebraska force majeure clause certainly was a contributing factor in the universities' eventual settlement of the lawsuit. The game contract provided Akron with a game guarantee of \$1.17 million. The parties ultimately settled for $\$ 650,000$ and an agreement to schedule another game between them in 2025, including a \$1.45 million game guarantee for Akron (McKewon, 2018b).

These two examples of game cancellation disputes further highlight the realistic probability of similar conflicts occurring in the future. These disputes also indicate the complex challenges faced by universities contemplating or facing legal action involving issues of contract interpretation when those contracts are unclear and unambiguous. While it would be unrealistic to attempt to delineate every potential weather-related event into a force majeure clause, an examination of current language in game contracts may be helpful to understand the different approaches to defining weather-related force majeure events and whether these provisions are adequately anticipating and allocating the risks related to game cancellations due to hurricanes and similar extreme weather events.

\section{Method}

To assess language used in college football contracts' force majeure provisions, especially in cases that experienced game disruptions due to extreme weather, this study utilized a qualitative approach through a document analysis. The researchers employed multiple data collection methods. First, Freedom of Information Act (FOIA) public records requests for football game contracts were submitted to Division I public universities. Under FOIA, the public has "the right to request access records from any federal agency," including public universities ("What is FOIA?" n.d., para. 1). Because private universities are exempt from complying with FOIA, requests were not made directly to those schools. However, agreements for contests between a private and a public institution were also targeted by making the request through the public university. Requests were made by asking for copies of game contracts for specific football contests between 2017 and 2020. Requests for game contracts for altered games (cancellations, postponements, relocations, etc.) specifically noted the game's alteration and intervening event (i.e., Hurricane Irma). A total of 55 requests were made, including to universities who reported cancelled, delayed, or relocated football games between the 2017 and 2020 college football seasons, universities in areas documented to have been impacted by extreme weather, and geographic regions 
that regularly report hurricanes such as Florida, Texas, and states along the Gulf of Mexico and Atlantic Ocean. Second, the FOIA requests were supplemented by Internet searches and media inquiries for additional game contracts for review. All contracts were provided free of cost and represent a variety of geographic regions and athletic conferences.

The data collection process yielded a total of 42 responses consisting of 36 complete game contracts including force majeure provisions. Responses also included two athletic conference templates and four interscholastic association templates. For the purposes of this study's analysis, the interscholastic association templates and athletic conference templates were excluded since an initial examination revealed they either did not contain specific force majeure provisions or they did not reflect an arms-length negotiation between the parties. Thus, the researchers independently reviewed and analyzed each of the remaining 36 individual game contracts. In order to evaluate the game contract language, a systematic analysis was performed. First, the researchers reviewed the dates, choice of law provisions, game guarantees, liquidated damages, and any language referencing force majeure, impossibility, cancellation, or other provision in each contract tending to excuse performance for failure to play the game. Looking specifically into force majeure provisions, the researchers then analyzed these clauses regarding specific language incorporating any or all of the elements of common law impossibility, general descriptions of acts of God or natural forces, and variations in describing specific weather conditions in the force majeure clause. The force majeure provisions were further analyzed to capture whether the contracts utilized catch-all phrases and how such phrases were used in describing force majeure events.

\section{Findings}

In the present study, force majeure provisions in college football game contracts were examined and compared to identify essential terms defining the scope of the provision and which events were expressly specified in the contract as a force majeure event. The review also evaluated the specificity with which extreme weather-related events were expressly anticipated by the parties and mutually agreed to permit cancellation of the agreement or excuse one party's performance under the contract.

Of the 36 game contracts analyzed, two did not contain some type of force majeure or impossibility clause, and another two did not delineate specific force majeure events. Of the 32 remaining game contracts, 15 contained "force majeure," "impossibility," or "cancellation" provisions that specifically identified various types of weather-related events among the listed force majeure triggering events (hereinafter referred to as "weather clauses"). Seven game contracts 
failed to expressly include weather events in their force majeure provisions. The remaining 10 game contracts included only general descriptions of force majeure events including "acts of God," "natural disaster," and "acts of God and Nature." Table 1 provides a summary of the game contracts expressly incorporating weather-related events into the force majeure clause. Additionally, eight contracts from the sample involved games scheduled that were subject to cancellation due to an extreme weather event, specifically Hurricanes Irma and Harvey in 2017, and Florence in 2018 (see Table 1).

Of the 15 weather clauses contained in the force majeure provisions, only six explicitly listed hurricanes. Those six contracts with specific inclusion of "hurricanes" involved universities located in just four states (Florida, Georgia, South Carolina, and Tennessee). It is important to note hurricanes also often cause flooding, which was also specifically listed in those six contracts with hurricane force majeure events, as well as in four additional game contracts. Floods $(n=9)$, hurricanes $(n=5)$, and tornados $(n=5)$ were the most listed specific extreme weather events. Table 2 reports the range of acts of God or natural forces descriptors, including specific weather-related terminology contained in the sample game contracts.

\section{Discussion}

Consistent with expected industry practices, almost all ( $n=34,94.44 \%$ ) contracts reviewed contained a form of "force majeure," "impossibility," or "cancellation" provision anticipating the possibility that one or more parties to the agreement may fail to appear or otherwise cancel a scheduled game. Yet of those 34 contracts, less than half (44.12\%) included weather-specific events in the force majeure clause despite the fact that three of the states were located in what has been described as tornado alley, and eight of the states were coastal or gulf states subject to increasing frequency and severity of hurricanes (NOAA, n.d.). Additionally, the six contracts specifically delineating hurricanes as a force majeure event were restricted to just four southeastern states that would be reasonably expected to experience hurricane-related weather events with greater frequency than other states included in the sample contracts. Surprisingly, due to the reach and damage of recent hurricanes, neighboring coastal, gulf, and even inland schools have not adopted such language, namely North Carolina, Virginia, Alabama, Louisiana, Mississippi, and Texas. Interestingly, six game contracts included both "acts of God" language and specific weather language. However, it is not clear whether combining the generic "acts of God" language together with specific weather language would expand or shrink the types of weather-oriented natural disasters that could potentially interfere with contract performance. It is possible that "acts of God" could be interpreted to mean any 
Table 1. Overview of College Football Game Contracts

\begin{tabular}{|c|c|c|c|}
\hline Contracting Parties & Athletic Conferences & $\begin{array}{l}\text { Force Majeure } \\
\text { Sections or } \\
\text { Clauses }\end{array}$ & Language Used \\
\hline North Carolina v. Central Floridac & ACC; American & Force Majeure & No weather events identified \\
\hline North Carolina v. James Madison & ACC; Colonial & Force Majeure & No weather events identified \\
\hline Florida v. Georgia (City of Jacksonville) & SEC & Force Majeure & Acts of god, weather \\
\hline Houston v. Texas - San Antonio ${ }^{b}$ & American; C-USA & Force Majeure & Severe weather conditions \\
\hline Florida v. Northern Colorado ${ }^{\mathrm{a}}$ & SEC; Big Sky & Force Majeure & Hurricane, tornado \\
\hline Florida v. South Florida & SEC; American & Force Majeure & Hurricane, tornado \\
\hline Louisville v. Indiana State & ACC; Missouri Valley & Force Majeure & Acts of God or other disasters \\
\hline Indiana v. Florida International ${ }^{a}$ & Big 10; C-USA & Force Majeure & Inclement weather \\
\hline South Carolina v. East Carolina & SEC; American & Force Majeure & Hurricane, tornado \\
\hline Clemson v. Citadel & ACC; Southern & Force Majeure & No weather events identified \\
\hline South Carolina v. Wofford & SEC; Southern & Force Majeure & Hurricane, tornado \\
\hline Texas v. South Florida & Big 12; American & Force Majeure & Acts of God, natural disaster \\
\hline South Carolina v. Coastal Carolina & SEC; Sunbelt & Force Majeure & Hurricane, tornado \\
\hline Arkansas State v. Miami ${ }^{a}$ & Sunbelt; ACC & Force Majeure & No weather events identified \\
\hline NC State v. Ball State & ACC; Mid-American & Force Majeure & No weather events identified \\
\hline Rice v. LSU & C-USA;SEC & Force Majeure & $\begin{array}{l}\text { Acts of God, unusually severe } \\
\text { weather }\end{array}$ \\
\hline Indiana v. Cincinnati & Big 10; American & Force Majeure & No weather events identified \\
\hline Purdue v. Wake Forest & Big 10; ACC & Force Majeure & No weather events identified \\
\hline Washington State v. San Jose State & PAC-12; Mountain West & Force Majeure & An act of God \\
\hline $\begin{array}{l}\text { University of Arkansas War Memorial Stadium } \\
\text { Lease Agreement for Missouri Game }\end{array}$ & SEC & Force Majeure & $\begin{array}{l}\text { Act of god, natural } \\
\text { disaster, tornado, lighting (sic), } \\
\text { anticipation of severe storms or } \\
\text { other inclement weather }\end{array}$ \\
\hline Southern Mississippi v. Appalachian State ${ }^{c}$ & C-USA; Sunbelt & Force Majeure & No FM events delineated \\
\hline Florida International v. Alcorn State ${ }^{\mathrm{a}}$ & C-USA; SWAC & Force Majeure & An Act of God, weather conditions \\
\hline Wisconsin v. Florida Atlantic ${ }^{\mathrm{a}}$ & Big 10; C-USA & Impossibility & Acts of God and Nature \\
\hline Tennessee v. South Alabama & SEC; Sunbelt & Impossibility & Severe weather conditions \\
\hline Colorado State v. Oregon State & Mountain West; PAC-12 & Impossibility & No FM events delineated \\
\hline Tennessee v. Georgia State & SEC; Sunbelt & Impossibility & Hurricane, tornado \\
\hline Missouri v. BYU & SEC; Mountain West & Cancellation & An Act of God \\
\hline Notre Dame v. New Mexico & Independent; Mountain West & Cancellation & Act of God, natural disaster \\
\hline Michigan v. Hawaii & Big 10; Mountain West & Cancellation & Inclement weather, Act of God \\
\hline Notre Dame v. Purdue & Independent; Big 10 & Cancellation & Act of God, natural disaster \\
\hline Oregon State v. Oklahoma State & PAC-12; Big 12 & Natural Disasters & or other Acts of God and Nature \\
\hline Oregon State v. Portland State & PAC-12; Big Sky & Natural Disasters & or other Acts of God and Nature \\
\hline New Mexico State v. New Mexico & Independent; Mountain West & Intervening Events & Natural disaster \\
\hline Michigan v. Appalachian State & Big 10; Sunbelt & $\begin{array}{l}\text { No Heading } \\
\text { (Para. 12) }\end{array}$ & Inclement weather, an act of God \\
\hline New Mexico v. Liberty & Mountain West; Independent & No Force Majeure & Not applicable \\
\hline New Mexico v. Sam Houston State & Mountain West; Southland & No Force Majeure & Not applicable \\
\hline
\end{tabular}

$N=36$

${ }^{a}$ Game impacted by Hurricane Irma

${ }^{b}$ Game impacted by Hurricane Harvey

'Game impacted by Hurricane Florence 
Table 2. Specific Acts of God or Natural Forces Events and Catch-All Phrase Variations Specified in Football Game Contracts

\begin{tabular}{l|l}
\hline $\begin{array}{l}\text { Acts of God or Natural } \\
\text { Forces }\end{array}$ & Catch-All Phrase Variations \\
\hline $\begin{array}{l}\text { Acts of God } \\
\text { Acts of Nature }\end{array}$ & - Any circumstance making it impossible to play \\
Fire & - Any circumstance making it impossible or impractical to play \\
Lightning & - Including without limitation \\
Flood & - Any other cause beyond the control of the party \\
Earthquake & - Any other cause beyond its reasonable control \\
Hurricane & control of a party \\
Tornado & - Any other material event that is beyond the reasonable control of a party \\
Volcanic Eruption & - Including but not limited to \\
Natural Disaster & - Any other reason similar or dissimilar beyond party's control \\
Weather & - Any similar cause beyond reasonable control of the party obligated to \\
Weather Conditions & render performance \\
Inclement Weather & - Any other crisis beyond the control of parties \\
Other Inclement Weather & - Conditions entirely beyond the control of defaulting party \\
Severe Weather & - Any similar reason not reasonably within the control of the party and \\
Severe Weather Conditions & which is ordinarily considered an event of force majeure \\
Anticipation of Severe Storms & - An extraordinary event or circumstance beyond the control of the parties \\
Unusually Severe Weather & \\
Power Failure & \\
Epidemic/Epidemics & \\
Explosion & \\
Failure of Public Utilities & \\
\hline
\end{tabular}

Note: Adapted from Encinas, C. A. (2011, Winter). Clause majeure? Can a borrower use an economic downturn or economic downturn-related event to invoke the force majeure clause in its commercial real estate loan documents. Real Property, Trust, and Estate Law Journal, 45, 733-776, at p. 739.

natural disaster other than weather-related events, especially given the nature of human involvement in climate change. It is also possible that "acts of God" followed by a list of events that include weather events would expand the types of weather events to include any of the specified weather events and other weather events that would also be considered an "act of God."

Beyond the list of force majeure events, the force majeure clauses also adopted varying approaches to how disruptive the events must be to qualify as a force majeure event, and whether such events had to be unforeseeable. With regard to how disruptive the force majeure events must be, 11 of the 15 contracts containing weather clauses required that performance (i.e., playing the game) must become "impossible" $(n=6)$ or "impossible or impractical" $(n=5)$ as a result of a force majeure event. The four contracts that do not include the "impossibility" standard only required that the game is canceled, a party fails to appear, or a party is prevented from appearing due to one of the specified force majeure events. The inclusion of the impossibility language in the force majeure provision could impose a similar standard as applied under the common law of 
impossibility - that it is, in fact, impossible to play the game due to the force majeure event. Whether the impossibility standard would be given a narrow scope (i.e., performance cannot be done) or interpreted less harshly that does not require absolute impossibility, but instead a standard similar to commercial impracticability, would vary depending on state law.

If the absolute impossibility standard were applied, it is likely it would preclude a force majeure claim in which the logistics of travel, travel expenses, duration of travel, or mode of transportation were impacted by extreme weather, making it more difficult or costly to appear for the game, but not impossible. For example, recall the University of Miami's stated reasons for not wanting to travel to Arkansas for its game against Arkansas State prior to the arrival of Hurricane Irma due to concerns that return travel plans might be complicated if the hurricane were to cause significant damage or travel delays. These concerns would likely not be sufficient in many states under the absolute impossibility standard, but might have a greater likelihood for success in states that adopt a broader view of impossibility coupled with a force majeure clause including both "impossible or impractical" as the standard for triggering force majeure coverage. Just two contracts included financial considerations as a force majeure event. Oregon State included language in two of its contracts voiding the contract "in the event it becomes impossible to play the said contest for the ... failure of the Oregon Legislative Assembly to appropriate funds sufficient to meet this obligation" (Oregon State University, n.d., para. 11). However, while financial circumstances are included among the force majeure events, those circumstances must still render performance impossible to void the contract.

For those provisions that included impossibility or impracticability, it could be argued that some of these occurrences making it more difficult, or costly to travel or appear, may meet the standard of commercial impracticability and the performance could be excused. However, even courts applying the impracticability standard have consistently required excessive or unreasonable costs or burdens, not just increased costs or increased difficulty, to satisfy an impracticability excuse.

Our initial review also identified whether the force majeure provision included "catch-all" phrases in an effort to expand the potential list of force majeure events covered by the clause. Two distinct approaches emerged from the review, also detailed in Table 2. First, and most frequently used $(n=9)$, were the common catch-all phrases: "or any other crisis," "or other unforeseen catastrophe or disaster," and "or any circumstance." When the parties use these types of phrases, they are attempting to avoid the court limiting the list of force majeure events to only those expressly specified in the list of examples. Courts are generally willing to assume the parties intended the list of force majeure events to not be an 
exhaustive list when these catch-all phrases are used. However, the contract rule of ejusdem generis will typically be applied to the catch-all phrase and prevent expanding the scope, type, or nature of the events included. This principle of contract interpretation holds that general terms following a series of specific terms are limited to a meaning substantially similar to the specific terms. For example, while the list might not be exhaustive, the event being asserted as covered by the catch-all phrase must still be the same type and nature of event described specifically. Thus, if the force majeure clause specifies inclement weather, but does not specify hurricane, and if the force majeure clauses include a catch-all phrase such as "or any other such disaster or catastrophe," a hurricane would be similar enough to other inclement weather to likely be included among the applicable force majeure events. However, if the force majeure clause is similar to the clause included in the UNC v. UCF (2018-2020) game contract that only lists "fire, flood, earthquake" without a catch-all phrase, a hurricane or other extreme weather event may not be included among the force majeure events, which would excuse the non-performance of one of the parties (Atlantic Coast Conference, 2016, para. 13). Some of the catch-all phrases incorporated this legal standard by expressly qualifying the catch-all phrase with "any similar reason" (City of Jacksonville [Florida v. Georgia], 2017, para. 28).

Perhaps in an effort to avoid the common limiting interpretation of the catchall phrase, one contract stated, "including but not limited to ... or any other reason similar or dissimilar" (War Memorial Stadium License Agreement, 2018, para. 27). This is a very broad catch-all phrase, and whether a court would permit such phrase to expand the types of force majeure events beyond those specifically described would depend upon the state law applicable to the contract. In this instance, it is a lease agreement between the University of Arkansas and War Memorial Stadium Authority to host the Arkansas v. Missouri football game in 2021. The contract contains a choice of law provision specifying that Arkansas law controls the interpretation of the agreement. Arkansas courts subscribe to the common-law contract rule of ejusdem generis for interpreting general terms following a series of specific terms, and limiting the general terms to a meaning substantially similar to the specific terms (Union Bankers Ins. Co. v. Nat'l Bank of Com. of Pine Bluff, 1966). Thus, despite the parties' inclusion of "similar or dissimilar" language in the catch-all phrase, it is not clear that the Arkansas courts would include other types of events. This is especially so given the specificity with which weather-related events were mentioned in the force majeure event list: tornado, lighting (sic), anticipation of severe storms, or other inclement weather. While it is likely hurricanes, heavy rainfalls, high winds, and hail could all fall easily within the catch-all's of "other inclement weather," and "any other reason similar or dissimilar," even these broad phrases may not 
extend the protection of the force majeure to other types of events that are not weather-related such as a pandemic or epidemic.

Two of the basic elements of common law impossibility (foreseeability and beyond the control of the parties) were also included in several force majeure clauses reviewed. Nine of the contracts expressly required that the cancellation or failure to appear was "beyond the control" $(n=6)$ or "beyond the reasonable control" ( $n=3$ ) of the party seeking to be excused from performance. Four of the contracts required that the circumstances causing cancellation or failure to appear to be "unforeseen" for a party to be excused from performance. Including unforeseeably in the force majeure clause adds another layer of difficulty for the party seeking to have its non-performance excused. One of the benefits of using a force majeure clause is that, unlike common law impossibility as a defense, force majeure events do not have to be unforeseen for them to entitle the parties to exercise their force majeure rights. Remarkably, two contracts included all three elements of common law impossibility: impossibility, beyond the control of the parties, and unforeseeability. Thus, the universities including this language in their game contracts or agreeing to the inclusion of this language in their game contracts have, for the most part, just replicated the elements of common law impossibility into their game contracts, rather than having carefully crafted a force majeure provision to allocate specific risks.

Overall, findings revealed a range of language inconsistencies within force majeure provisions in addition to the variety of catch-all phrases used to vaguely extend the potential reach of the force majeure provision. Specific weather-related, or extreme weather, events expressly listed in force majeure provisions also do not adequately reflect environmental realities faced by college football programs. Specifically, hurricanes and extreme weather are not sufficiently accounted for in force majeure provisions given the number of college football games altered specifically by them. The consequences of a poorly drafted force majeure provision can be significant given that almost all Division I game contracts will also include both game guarantee payments and liquidated damages provisions. Game guarantees can range from hundreds of thousands of dollars to as much as $\$ 3.5$ million. Liquidated damages for failure to play or unexcused cancellations similarly can range from hundreds of thousands of dollars to up to $\$ 3.0$ million. See Table 3 for a sample of game guarantee payments and corresponding liquidated damages provisions. The prevalence of game contracts that do not carefully consider the impact of force majeure events and rely on boilerplate language to address potential cancellations or disruptive events should be a primary concern for athletic administrators. 
Table 3. Sampling of College Football Game Contract Guarantees and Liquidated Damages

\begin{tabular}{l|c|c}
\hline & Game Guarantee & Liquidated Damages \\
\hline LSU v. Rice* & $\$ 3,500,000$ & $\$ 2,000,000$ \\
\hline Rice v. LSU* & $\$ 2,000,000$ & $\$ 2,000,000$ \\
\hline Wisconsin v. FAU & $\$ 1,200,000$ & $\$ 600,000$ \\
\hline NC State v. Ball State & $\$ 950,000$ & $\$ 3,000,000$ \\
\hline Florida v. Northern Colorado & $\$ 625,000$ & $\$ 625,000$ \\
\hline Louisville v. Indiana State & $\$ 500,000$ & $\$ 500,000$ \\
\hline Arkansas State v. Miami & $\$ 300,000$ & $\$ 650,000$ \\
\hline Florida International v. Alcorn State & $\$ 275,000$ & $\$ 550,000$ \\
\hline North Carolina v. Central Florida & $\$ 200,000$ & $\$ 1,500,000$ \\
\hline Indiana v. Florida International & $\$ 200,000$ & $\$ 1,000,000$ \\
\hline Houston v. Texas - San Antonio & None & $\$ 500,000$ \\
\hline Florida v. Georgia & None & $\$ 25,000$ \\
\hline
\end{tabular}

*Single games in a two-game contract

\section{Recommendations}

Natural disasters will continue to occur more frequently and with greater severity, thus, the impact on contractual obligations will be a continuing and growing concern (Emanuel, 2017; Goldfarb, 2005; Kunreuther \& Michel-Kerjan, 2007). Parties seeking to be excused from contractual performance and avoiding a breach of contract should be particularly invested in how the force majeure clause is drafted and interpreted in their contract (Sniffen, 2007). Boilerplate or vague language leaves numerous grey areas in force majeure provisions of college football game contracts. Declercq (1995) composed a brief checklist for formulating a force majeure clause that includes useful suggestions for those drafting game contracts.

First, is to clarify who can invoke the clause. Our analysis revealed most contracts afforded protection to both parties; however, one contract did restrict the protections to the home team only. This type of clarity could have avoided the dispute between Arkansas State and Miami since as the visiting team, Miami would not have been entitled to invoke the force majeure clause.

Second, is whether to make the force majeure clause exclusive, thereby foreclosing common law impossibility claims. Due to the considerable variation 
between state law force majeure principles and the fact that many game contracts cover multiple games in both states over a number of years, it might be wise to stipulate that the force majeure remedies are the exclusive remedies in the event of game cancellations.

Third, the contract should address whether alternative or substitute performance is available or required. In the game contract context, this would manifest itself in stipulating whether a game cancelled pursuant to the force majeure clauses would need to be rescheduled and the process for rescheduling. Given the length of these agreements and lack of flexibility in most football program schedules, the parties should be clear what level of effort must be used to reschedule and a time frame for rescheduling. Recall, the settlement between Akron and Nebraska included a rescheduled game in 2025 as part of the accommodation to Akron for the cancellation.

Fourth, the force majeure clause should contain a definition of force majeure that can be based on events, effects, or a combination of the two. Declercq (1995) preferred an effects-based definition partly to minimize the impact of the ejusdem generis canon of interpretation. A force majeure clause in game contracts needs to clearly and specifically identify force majeure trigging events, which was a practice followed by almost all the contracts reviewed. However, an example of also anticipating effects of cancellation is found in those contracts specifically providing for allocation of costs and expenses in case of cancellation.

Fifth, a force majeure clause should clarify the role of foreseeability in interpreting the force majeure defined events or effects. As mentioned, several game contracts analyzed imposed a foreseeability standard upon the parties seeking a force majeure remedy. This is unnecessary and is likely to only add confusion and ambiguity in the contract.

Sixth, the force majeure clause should establish a standard for the inability to perform and how it is to be measured. Addressing this in the clause can avoid venturing into the impossibility or impracticability quagmire, and instead allow the parties to acknowledge and decide if disruptions in travel, increased travel costs, logistics, or other financial exigency will excuse performance.

Lastly, going forward, more consideration might need to be given in determining the legal consequences of human intervention in weather-related events, or a separate discussion should be had on game cancellations due to weather independently from force majeure.

\section{Conclusion}

With climate escalation, traditional contract language may not continue to rely on general "acts of God" as a safe and understood term. This study presented 
several concerns related to force majeure clauses in college football game contracts and revealed inconsistencies and inadequacies in these clauses. Furthermore, recommendations were made that those provisions be revised and reconstructed to meet current, realistic needs for individual schools. The present study highlighted the issues associated with a conference model of contract formulation often adopted by schools, and the lack of regular revisitation of these documents given drastic environmental changes of late by shedding light on the scope of force majeure. Although the onset of the novel coronavirus pandemic warranted immediate revisitation of college football contracts and 2020 schedules, gradual, yet recurring, climate-related disruptions have the potential to affect the future of college football. Societal consciousness regarding climate change, and associated events of extreme weather like hurricanes, is adjusting; therefore, sport and legal practitioners can reflect this modernization by scrutinizing their contractual agreements more closely and carefully allocating risks.

\section{References}

1 Am Jur 2d Act of God $\S 2$ (2005)

1 Am Jur 2d Act of God $\S 3$ (2005)

1 Am Jur 2d Act of God $\S 4$ (2005)

Abraham, A. (2018, September 5). Cancellation of Akron's football opener against Nebraska puts possible large payout in jeopardy. WKYC Studios. Retrieved from https://www.wkyc.com/ article/sports/high-school/football/cancellation-of-akrons-football-opener-against-nebraska-puts-possible-large-payout-in-jeopardy/95-590860960

Act of God. (n.d.). In the People's Law dictionary. Retrieved from https://dictionary.law.com/ Default.aspx?selected $=2318$

Am. Aviation, Inc. v. Aero-Flight Serv., Inc, 1998

Atlantic Coast Conference. (2013, June 25). Football competition agreement between the University of Miami and Arkansas State University.

Atlantic Coast Conference. (2016, July 26). Football competition agreement between the University of North Carolina at Chapel Hill and the University of Central Florida Athletics Association, Inc.

Bergin, N. (2005, September 21). Force majeure issues relating to Katrina. Jones Walker. Retrieved from https://www.joneswalker.com/images/content/1/1/v2/1176/249.pdf

Berkowitz, S. (2017, September 8). Canceling football games due to Hurricane Irma brings financial complications for schools. USA Today. Retrieved from https://www.usatoday.com/story/ sports/ncaaf/2017/09/08/canceling-football-games-due-hurricane-irma-brings-financial-complications-schools/646699001/

Brener, S. R. (2006). Comment: Outgrowing impossibility: Examining the impossibility doctrine in the wake of Hurricane Katrina. Emory Law Journal, 56, 461-505.

Cangialosi, J. P., Latto, A. S., \& Berg, R. (2018). Tropical cyclone report: Hurricane Irma (AL112017). National Oceanic and Atmospheric Administration, National Hurricane Center. Retrieved from https://www.nhc.noaa.gov/data/tcr/AL112017_Irma.pdf 
Chappell, B. (2017, September 12). Hurricane Irma blasts into the record books with lasting intensity. National Public Radio. Retrieved from https://www.npr.org/sections/thetwo-way/2017/09/12/550188154/hurricane-irma-blasts-into-the-record-books-with-lasting-intensity

City of Jacksonville. (2017, November 7). Amendment and restatement of agreement for 2017-2021 between the University of Florida and the University of Georgia.

Crowe, J. (1998, September 25). UCLA game canceled, by Georges. Los Angeles Times. Retrieved from https://www.latimes.com/archives/la-xpm-1998-sep-25-sp-26290-story.html

Culpepper, J. E. (2017, September 12). Hurricane Irma: A complete list of college football's canceled, delayed Week 3 games. The Atlanta Journal Constitution. Retrieved from https://www. ajc.com/sports/hurricane-irma-complete-list-college-football-canceled-delayed-week-games/ u4O0BVgfCA2mYMEG7fGTdM/

Declercq, P. J. M. (1995). Modern analysis of the legal effect of force majeure clauses in situations of commercial impracticability. The Journal of Law and Commerce, 15, 1-41.

Dellinger, M. (2016). An "Act of God"? Rethinking contractual impracticability in an era of anthropogenic climate change. Hastings Law Journal, 67(6), 1551-1620.

Dinan, T. (2017). Projected increases in hurricane damage in the United States: The role of climate change and coastal development. Ecological Economics, 138, 186-198. https://doi.org/10.1016/j. ecolecon.2017.03.034

Emanuel, K. (2017). Assessing the present and future probability of Hurricane Harvey's rainfall. Proceedings of the National Academy of Sciences of the United States of America (PNAS), 114(48), 12681-12684. https://doi.org/10.1073/pnas.1716222114

Encinas, C. A. (2011, Winter). Clause majeure? Can a borrower use an economic downturn or economic downturn-related event to invoke the force majeure clause in its commercial real estate loan documents. Real Property, Trust, and Estate Law Journal, 45, 733-776.

Geophysical Fluid Dynamics Laboratory, National Oceanic and Atmospheric Administration. (2018). Global warming and hurricanes: An overview of current research. National Oceanic and Atmospheric Administration. Retrieved from https://www.gfdl.noaa.gov/global-warming-and-hurricanes/

Goldfarb, N. J. (2005). Hurricane Katrina: There's more where that came from. Journal of Clinical Research Best Practices, 1(10), 1-6.

Hall, T. J. (2017). Defenses of impossibility of performance and frustration of purpose. Law Journal Newsletters. Retrieved from http://www.lawjournalnewsletters.com/sites/lawjournalnewsletters/2017/12/01/defenses-of-impossibility-of-performance-and-frustration-of-purpose/?slre$\underline{\text { turn }=20180825140833}$

Hilton Oil Transport v. Oil Transport Co, S.A., 659 So.2d 1141 (Fla. 3d DCA 1995).

Katsivela, M. (2007). Contracts: Force majeure concept or force majeure clauses. Uniform Law Review, 12, 101-120. https://doi.org/10.1093/ulr/12.1.101

Katz, M., Dixon, M. A., Heere, B., \& Bass, J. R. (2017). Front porch, small house: A longitudinal study of team and university identification among incoming students at a Division III university. Journal of Intercollegiate Sport, 10(1), 103-125. https://doi.org/10.1123/jis.2016-0043

Kelley, J. D. (2007). So what's your excuse - An analysis of force majeure claims. Texas Journal of Oil, Gas, \& Energy, 2, 91-124.

Kirk, J., \& Godfrey, S. (2017, September 2). Why BYU moved to New Orleans and not elsewhere: The choice of NOLA over other options is a little complicated. SBNation. Retrieved from https://www.sbnation.com/college-football/2017/8/29/16221376/1su-byu-new-orleans-houston-hurricane-harvey 
Kubena, B. (2018, February 17). ASU true to word, files lawsuit against Miami over canceled football game. Arkansas Democrat Gazette. Retrieved from https://www.arkansasonline.com/ news/2018/feb/17/asu-true-to-word-files-against-miami-20/

Kunreuther, H. C., \& Michel-Kerjan, E. O. (2007). Climate change, insurability of large-scale disasters, and the emerging liability challenge. University of Pennsylvania Law Review, 155(6), 1795-1841. https://doi.org/10.3386/w12821

Lau, T., \& Johnson, L. (2011). The legal and ethical environment of business. Retrieved from https://open.umn.edu/opentextbooks/textbooks/51

Marathon Sunsets, Inc. v. Coldiron, 189 So.3d 235 (Fla. 3d DCA 2016).

May, S. (Ed.) (2017). What are hurricanes? National Aeronautics and Space Administration. Retrieved from https://www.nasa.gov/audience/forstudents/k-4/stories/nasa-knows/what-are-hurricanes-k4.html

McKewon, S. (2018a, September 4). Huskers would've owed Akron \$1.17 million, but deal may be void after cancellation. Omaha World-Herald. Retrieved from https://omaha.com/sports/college/huskers/teams/football/huskers-wouldve-owed-akron-1-17-million-but-deal-may-be-voidafter-cancellation/article 7ef5934b-3385-5e68-9cf9-1d6eb19be399.html

McKewon, S. (2018b, December 17). Nebraska agrees to pay Akron $\$ 650,000$ for canceled game, and teams will play in 2025. Omaha World-Herald. Retrieved from https://omaha.com/sports/ college/huskers/teams/football/nebraska-agrees-to-pay-akron-650-000-for-canceled-game-andteams-will-play-in/article 099b7f0f-9flc-5b1f-bc49-el106a3ff6d0.html

Meyers, J., \& Sheinkin, A. (2012). The ins and outs of fair "weather clauses" in power project contracts. American Bar Association Natural Resources \& Environment, 27, 1-7.

Miller, K., \& Rice, D. (2020, August 21). Two Gulf hurricanes at the same time? Tropical Storms Laura, Marco have formed. USA Today. Retrieved from https://www.usatoday.com/story/news/ nation/2020/08/21/florida-gulf-hurricanes-nhc-forecasts-two-tropical-depressions/3406310001/

Moriarty, M. (2017, September 6). What do game contracts say about canceling? Well, let's look at one example. SBNation. Retrieved from https://www.sbnation.com/college-football/2017/9/6/16261978/college-football-game-canceled-what-happens-contract

Moore, J. (2017, August 30). List of high school football games moving due to Hurricane Harvey weather system. Lexington Herald Leader. Retrieved from https://www.kentucky.com

Murray, T. (2020, June 16). Force majeure and coronavirus (COVID-19): Seven critical lessons from the case law. Lexis Practice Advisor Journal. Retrieved from https://www.lexisnexis.com/ lexis-practice-advisor/the-journal/b/lpa/posts/force-majeure-and-coronavirus-covid-19-sevencritical-lessons-from-the-case-law

Nestel, D. (2006, February). Force majeure clauses: The basics. Construction Executive, 42-43.

NOAA. (n.d.). Tornado alley. National Centers for Environmental Information. Retrieved from https://www.ncdc.noaa.gov/climate-information/extreme-events/us-tornado-climatology/tornado-alley

Oregon State University. (n.d.). Natural disaster clauses included in game contract between Oregon State and Oklahoma State University.

Phelps, B. (2018, February 12). [Email to James D. Rowlee]. Retrieved from http://kait.images. worldnow.com/library/6bf15ebb-cb5b-4b1e-84d6-2c2c8a0b59e6.pdf

Restatement of Contracts $\S 261$.

Russo, R. D. (2018, September 14). Hurricane stokes talk of extending college football season. Associated Press News. Retrieved from https://apnews.com/f2a93de266f948be9f47104bb4008b88 
Rowlee, J. D. (2018, February 9). [Email to Brad Phelps]. Retrieved from https://media.arkansasmatters.com/nxsglobal/arkansasmatters/document_dev/2018/02/12/Miami\%20Letter\%20to\%20 ASU_2_9_18 1518462384853_33982579 ver1.0.pdf

Shapiro, M. (2018, September 3). Nebraska and Akron's contract doesn't provide answer for void payment. Sports Illustrated. Retrieved from https://www.si.com/college/2018/09/03/nebraska-akron-football-contract-void-provisions

Sherman, M. (2018, September 1). Severe weather forces cancellation of Akron-Nebraska, South Dakota State-Iowa State. ESPN. Retrieved from https://www.espn.com/college-football/story/ / id/24552041/akron-nebraska-college-football-games-canceled-due-severe-weather

Siegfried, J. J., \& Burba, M. G. (2004). The College Football Association television broadcast cartel. The Antitrust Bulletin, 49(3), 799-819. https://doi.org/10.1177/0003603X0404900309

Sniffen, J. (2007). In the wake of the storm: Nonperformance of contract obligations resulting from a natural disaster. Nova Law Review, 31(3), 1-25.

Spain, K. (2017, September 6). How Hurricane Irma is affecting college football this weekend. USA Today. Retrieved from https://www.usatoday.com/story/sports/ncaaf/2017/09/06/how-hurricane-irma-affecting-college-football-weekend/638457001/

Union Bankers Ins. Co. v. Nat'l Bank of Com. of Pine Bluff, 408 S.W.2d 898 (Ark. 1966).

University of Louisville v. Duke University, No. 07-CI-1765, Franklin Circuit Court, Commonwealth of Kentucky.

Urban Archaeology v. 207 East 57th Street, 34 Misc.3d 1222(A) 951 N.Y.S.2d 84 (N.Y. Co. 2009)

USA Today Sports. (2018, September 11). Hurricane Florence causes major changes to the college football schedule. USA Today. Retrieved from https://www.usatoday.com/story/sports/ ncaaf/2018/09/11/college-football-games-impacted-hurricane-florence/1272231002/

Varriale-Barker, C. (2020, May 19). More than words: The business of sports, COVID-19, and force majeure clauses. Sport Business. Retrieved from https://www.sportbusiness.com/2020/05/ carla-varriale-barker-more-than-words-the-business-of-sports-covid-19-and-force-majeureclauses/

War Memorial Stadium License Agreement. (2018, May). Agreement between Arkansas Department of Parks and Tourism and Board of Trustees of the University of Arkansas.

West, J. (2020, September 1). Ten UCF players opt out of 2020 football season due to coronavirus concerns. Sports Illustrated. Retrieved from https://www.si.com/college/2020/09/01/ucf-players-opting-out-2020-season-coronavirus

What is FOIA? (n.d.). Retrieved from https://www.foia.gov/about.html

Wong, G. (n.d.). Event cancellation: What is a game worth to your institution? AthleticDirectorU. Retrieved from https://athleticdirectoru.com/articles/event-cancellation-what-is-one-gameworth-to-your-institution/ 